\title{
Efektivitas Media Pembelajaran bagi Pendidik PAUD yang Ramah Lingkungan
}

\author{
Suwardi \\ Program Studi Pendidikan Anak Usia Dini, Fakultas Psikologi dan Pendidikan, \\ Universitas Al Azhar Indonesia, Jl.Sisingamangaraja, Jakarta 12110 \\ E-mail: suwardi@uai.ac.id
}

\begin{abstract}
Abstrak - Produktifitas dan kreatifitas pendidik yang optimal akan sangat berpengaruh besar terhadap perkembangan anak didik khususnya dalam penyampaian dan penyajian materi pembelajaran dalam proses belajar mengajar dengan menggunakan alat peraga. Alat peraga dari sisi pembuatan terbagi menjadi dua yakni yang berasal dari pabrik dan lingkungan sekitar. Sedangkan ditinjau dari segi kemanfaatan ternyata alat peraga lingkungan dapat diperoleh dengan cepat dan mudah serta murah, selain daripada itu alat peraga dalam proses belajar mengajar anak didik bertujuan akan cepat merespon dan memperrmudah pemahamannya yang berasal dari lingkungan sekitar.
\end{abstract}

Abstract - Productivity and creativity optimal educators will be very great influence on the development of students, especially in the delivery and presentation of learning materials in teaching and learning by using teaching aids. Teaching aids from the manufacture is divided into two derived from the plant and surrounding environment. While the terms of the environmental benefits were teaching aids can be obtained quickly and easily and cheaply, other than it teaching aids in the learning process students will quickly respond and aims to facilitate the understanding that comes from the surrounding environment.

Keywords - Students, instructional media, early childhood educators

\section{PENDAHULUAN}

$\mathrm{K}$ eberhasilan seorang pendidik manakala anak didik memahami dan dapat menerapkan pengetahuan, keterampilan dan sikap atau nilainilai yang terkandung materi pembelajaran yang disampaikan dari tujuan yang telah ditetapkan sebelumnya. Dari keberhasilan tersebut perubahan pengetahuan, keterampilan dan sikap ataupun nilainilai yang terkandung di dalamnya dari anak didik memerlukan proses pendidikan yang berkelanjutan.

Dengan demikian pendidikan bukan saja hak setiap anak dalam rangka mengembangkan dirinya dengan kondisinya (UU No. 20 tahun 2003 tentang perlindungan anak), tetapi merupakan kewajiban semua pihak, termasuk orang tua, masyarakat, pemerintah bahwa warga dunia, demikian maksud implementasi dari kebijakan education for all. Berpijak pada kerangka tersebut, pendidikan anak usia dini merupakan tanggung jawab bersama, maka upaya-upaya pengembangan PAUD harus mengikutsertakan seluruh elemen bangsa, termasuk pemerintah dalam menerapkan relulasi UndangUndang Pendidikan.

Pada tingkatan Pendidikan Anak Usia Dini (PAUD) mulai mendapat perhatian yang serius dari masyarakat, mengingat usia tersebut merupakan fase yang sangat krusial dalam pembentukan kepribadian anak. Masyarakat sendiri sadar bahwa pendidikan yang telah mereka lakukan terhadap anak-anaknya selama ini mengalami keterlambatan. Semula mereka meyakini bahwa pendidikan anak usia dini merupakan tanggung jawab orang tua atau keluarga saja tanpa melibatkan pihak lain, sehingga upaya yang dilakukan lebih terfokus pada perawatan dan pengasuhan, dan kurang memperhatikan aspek pendidikan. Mereka ingin mengejar keterlambatan pendidikan itu pada jenjang Sekolah Dasar, tetapi sesungguhnya hal itu telah kehilangan momennya, sebab secara psikologis anak usia dini telah mengalami perubahan fase dan tugas-tugas perkembangannya. 
Permasalahan pada pendidik PAUD adalah:

1) Pendidik yang kurang kreatif yakni kurang mengembangkan dan memanfaatkan potensi yang ramah lingkungan sebagai Alat Peraga Edukatif (APE).

2) Pendidik yang kurang peka, pendidik kurang memiliki kepedulian dengan menstimuli dan mengembangkan seluruh potensi dan dimensi kepribadian anak sesuai dengan keunikannya.

3) Pendidik kurang bermutu dan terpadu, pendidik yang kurang dapat mengoptimalkan kemampuan yang ada khusus pendidikan anak usia dini.

Penulisan ini bertujuan:

1) Terciptanya pendidik PAUD bermutu dan terpadu yang dapat menstimulasi dan mengembangkan seluruh potensi dan dimensi kepribadian anak sesuai keunikannya dengan memanfaatkan media pembelajaran yang ramah lingkungan.

2) Pendidik dapat memanfaatkan potensi yang ramah lingkungan sebagai Alat Peraga Edukatif (APE).

Adapun hasil yang diharapkan dalam hal ini adalah:

1) Pendidik kreatif yakni pendidk dengan mengembangkan dan memanfaatkan potensi yang ramah lingkungan sebagai Alat Peraga Edukatif (APE).

2) Pendidik yang peka, yakni pendidik memiliki kepedulian dengan menstimuli dan mengembangkan seluruh potensi dan dimensi kepribadian anak sesuai dengan keunikannya.

3) Pendidik bermutu dan terpadu, pendidik yang dapat mengoptimalkan kemampuan yang ada khusus pendidikan anak usia dini.

Sedangkan kegunaannya adalah untuk:

1) Memberikan pencerahan yang sangat membantu pendidik PAUD.

2) Mengoptimalkan sumber belajar yang ramah lingkungan.

3) Mengoptimalkan kemampuan pendidik yang ada khusus pendidikan anak usia dini.

\section{KERANGKA TEORI / TINJAUAN PUSTAKA}

Menurut Harlock, tugas-tugas perkembangan pada usia minggu ke-2 sampai usia 6 tahun adalah belajar memakan makanan padat, belajar berjalan, belajar berbicara, belajar mengendalikan pembuangan kotoran tubuh, mempelajari perbedaan seks dan tata caranya, mempersiapkan diri untuk berbicara, dan belajar membedakan benar dan salah, dan mulai mengembangkan hati nurani. Sedang usia 6 sampai dengan 10 tahun tugas-tugas perkembangan anak adalah mempelajari keterampilan fisik untuk jenis permainan umum, membangun sikap yang sehat mengenai diri sendiri sebagai makhluk yang sedang tumbuh, belajar menyesuaikan diri dengan teman-teman seusianya mulai mengembangkan peran sosial pria atau wanita yang tepat, mengembangkan keterampilan dasar seperti membaca, menulis dan berhitung, mengembangkan pengertian yang diperlukan untuk kehidupan sehari-hari, mengembangkan hati nurani, pengertian moral, dan tata dan tingkatan nilai, mengembangkan sikap terhadap kelompokkelompok sosial dan lembaga-lembaga dan mencari kebebasan pribadi.

Dari sudut teori apapun, baik medis-neurologis, psiko-sosial, psiko-edukatif, bahkan psiko-religius, pembentukan kepribadian seseorang sangat bergantung pada masa usia dini. Atas dasar itulah, pendidikan anak usia dini tidak boleh diabaikan, tetapi harus dilakukan secara bertahap, berkesinambungan dan berkelanjutan. Hasil studi menunjukkan bahwa produktifitas dan kreatifitas seseorang di masa dewasa sangat bergantung pada masa usia dini. Usia dini menjadi tolok ukur dalam memahami kesiapan seseorang, baik dari sudut kesiapan belajar, perawatan kesehatan maupun pengembangan semua potensi anak (Noor Rachman Hadjam, 2005)

Media berasal dari bahasa latin merupakan bentuk jamak dari "Medium" yang secara harfiah berarti "Perantara" atau "Pengantar" yaitu perantara atau pengantar sumber pesan dengan penerima pesan. Beberapa ahli memberikan definisi tentang media pembelajaran. Schramm (1977) mengemukakan bahwa media pembelajaran adalah teknologi pembawa pesan yang dapat dimanfaatkan untuk keperluan pembelajaran. Brown (1973) mengungkapkan bahwa media pembelajaran yang digunakan dalam kegiatan pembelajaran dapat mempengaruhi terhadap efektivitas pembelajaran.

Pada mulanya, media pembelajaran hanya berfungsi sebagai alat bantu guru untuk mengajar yang digunakan adalah alat bantu visual. Sekitar pertengahan abad Ke-20 usaha pemanfaatan visual dilengkapi dengan digunakannya alat audio, sehingga lahirlah alat bantu audio-visual. Sejalan dengan perkembangan ilmu pengetahuan dan teknologi (IPTEK), khususnya dalam bidang 
pendidikan, saat ini penggunaan alat bantu atau media pembelajaran menjadi semakin luas dan interaktif, seperti adanya komputer dan internet.

Media pembelajaran yang ramah lingkungan mengandung arti material yang digunakan adalah material organik dan non-toxic. Biasanya berbahan baku tanaman atau pohon dimana untuk pemanfaatannya cukup memakai bagian-bagian dari bunga, buah, dahan, ranting dan daun, tanpa harus mematikan atau menebangnya. Pendidik PAUD dan anak didik memposisikan lingkungan sebagai bagian dari dirinya, tidak rela terjadinya perusakan lingkungan hidup sekecil apapun, memposisikan setiap bagian dari alam adalah potensi sebagai media pembelajaran dan berprinsip bahwa untuk pemenuhan ketersediaan media pembelajaran, pengeksploitasian lingkungan hidup adalah dengan cara seperlunya.

\section{METODOLOGI PENELITIAN}

Efektivitas Media Pembelajaran bagi pendidik PAUD yang ramah lingkungan pada tujuan tersebut mengandung 3 (tiga) indikator utama, yaitu:

1) Pendidik Kreatif yakni dengan mengembangkan dan memanfaatkan potensi yang ramah lingkungan sebagai Alat Peraga Edukatif (APE), tentu saja aktifitas pembelajarannya yang dilakukan selaras dengan prinsip kebaikan, kemaslahatan dan manfaat bagi kehidupan anak didik. Pendidik kreatif akan pula melahirkan anak didik yang berjiwa inovatif dengan produktifitas yang tinggi sesuai dengan potensinya yang ada.

2) Pendidik yang peka, yakni pendidik memiliki kepedulian dengan menstimuli dan mengembangkan seluruh potensi dan dimensi kepribadian anak sesuai dengan keunikannya; Dalam diri anak terdapat sejumlah potensi yang dapat diaktualisasikan melalui proses pendidikan. Masing-masing anak memiliki bakat, minat, kecenderungan, dan kemampuan yang unik, baik yang terkait dengan ranah pendidikan, nilai-nilai kehidupan maupun potensi kecerdasan, sehingga tugas pendidikan hanyalah menstimulasi tumbuh-kembangnya berbagai keunikan itu. Proses pendidikan semacam itu menjadikan keberhasilan dalam transformasi nilai tanpa mengabaikan suasana kejiwaan anak yang menyenangkan.

3) Pendidik bermutu dan terpadu, pendidik yang dapat mengoptimalkan kemampuan yang ada khusus pendidikan anak usia dini, selain daripada itu memiliki kemampuan memadukan seluruh sumber daya dan dana potensial pendidikan anak usia dini yang ada.

Dalam melakukan kegiatan tersebut diperlukan beberapa tahap adalah sebagai berikut:

1) Persiapan, meliputi :

a. Pembuatan Alat Peraga Edukatif (APE)

b. Pembuatan buku pedoman APE

2) Pelaksanaan pelatihan: meliputi kegiatan pelatihan yang telah direncanakan

3) Penyusunan laporan kegiatan: meliputi pembuatan laporan hasil kegiatan pelatihan terintegrasi.

\section{HASIL DAN PEMBAHASAN}

Adapun teknis pembuatan Alat Peraga Edukatif (APE) dalam efektivitas Media Pembelajaran bagi pendidik PAUD yang ramah lingkungan sebagai berikut:

\subsection{Toples Pintar Bunda}

Tujuan:

Permainan ini bertujuan untuk mengenalkan bentuk (seperti buah-buahan), warna, mengucapkan kata, serta dapat melatih motorik halus anak.

Bahan dan Alat yang Diperlukan:

- Toples bekas plastik (yang transparan)

- Kardus atau karton bekas

- Kertas warna-warni atau origami

- Kertas bekas

- Spidol (untuk menggambar)

- Gunting

- Lem

Cara Membuat:

- Tempelkanlah kertas warna-warni diatas kardus

- Kemudian gambarlah (misal: buah, tetapi gambar dapat disesuaikan kebutuhan) diatas kertas tersebut. (untuk gambar buah harus disesuaikan dengan warna aslinya)

- Potonglah gambar kardus dan kertas yang telah ditempelkan sesuai dengan bentuk gambar.

- Tuliskan nama benda yang digambar diatas gambar (agar anak dapat mengetahui benda apa tersebut serta bagaimana pengejaan serta hurufnya)

- Tuliskan beberapa pertanyaan teka-teki dibalik gambar tersebut. 
- Setelah semua gambar telah dibuat masukan kedalam toples

- Kemudian potonglah sisa-sisa kertas menjadi bagian yang panjang-panjang (seperti bentuk mie) dan masukan kedalam toples.

- Kocoklah toples tersebut agar gambargambar dan kertas bercampur.

- Setelah itu berilah hiasan pada bagian luar toples agar terlihat lebih menarik

\section{Cara Menggunakan:}

- Buatlah permainan dengan anak, baik satu ataupun lebih. Permainan ini dapat dilakukan didalam atau diluar ruangan.

- Kemudian mintalah seorang anak memasukan tangan kedalam toples dan mengambil gambar buah yang ada didalam dengan cara mengaduk-mengaduknya.

- Setelah itu mintalah anak untuk menebak gambar atau bentuk apa tersebut.

- Anda dapat meminta anak-anak untuk mengulangi kata-kata tersebut.

- Setelah itu anda membacakan teka-teki yang ada dibalik gambar tersebut.

\subsection{My Family's Tree}

Tujuan:

Permainan ini bertujuan untuk memperkenalkan bentuk (seperti buah-buahan), warna, mengucapkan kata, serta dapat melatih motorik halus anak.

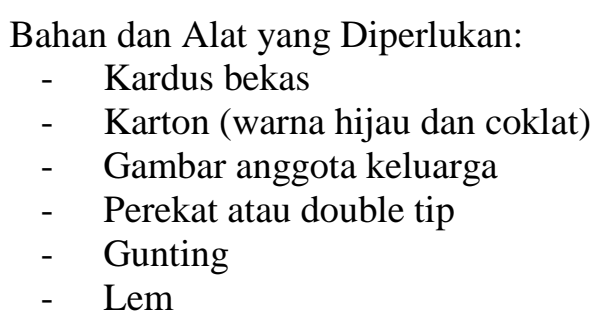

\section{Cara Membuat:}

- Guntinglah kardus membentuk sebuah pohon

- Tempelkan karton hijau pada bagian pohon dan potong mengikuti bentuk kardus, begitu juga tempelkan karton coklat pada kardus yang berbentuk batang pohon.

- Siapkanlah kartu gambar anggota keluarga mulai dari kakek, nenek, sampai dengan adik dengan ukuran yang sama, dan jangan lupa untuk menuliskan kata (misal AYAH) pada kartu gambar.

- Buatlah garis keturunan pada bagian pohon mulai dari KAKEK dan NENEK sampai keturunan akhir.
- Tempelkan kartu-kartu tersebut pada tiap garis (buatlah agar kartu-kartu tersebut tidak menempel secara permanen agar mudah dibongkar pasang oleh anak).

- Hiaslah pohon tersebut sekreatif mungkin

Cara Menggunakan:

- Pada saat kegiatan belajar mengajar dengan tema keluarga, Family's tree dapat digunakan sebagai media pengenalan kepada anak mengenai peran-peran yang terdapat dalam keluarga.

- Kemudian kenalkan anak pada tiap gambar anggota keluarga beserta pengucapannya serta jelaskan kepada anak bagaimana peran tiap anggota.

- Setelah itu copotkan gambar dari pohon dan mintalah anak untuk menempelkannya kembali pada garis yang tepat.

\subsection{Mencocok Angka}

Tujuan:

Permainan ini bertujuan untuk memperkenalkan konsep angka 1-5, Perabaan, warna, serta bentuk.

Bahan dan Alat yang Diperlukan:

- Kardus

- Bahan sisa atau kain perca

- Kertas origami

- Beras, kacang hijau, busa, pasir atau tepung (sebagai isi)

- Cutter

- Benang

- Jarum

Cara Membuat:

- Siapkanlah kardus berukuran kurang lebih 30x30 cm sebanyak 5 buah

- Kemudian bolongkanlah tiap kardus membentuk angka mulai dari 1 sampai 5 .

- Berilah warna pada tiap potongan angka menggunakan kertas origami yang berwarnawarni.

- Setelah itu pada bagian samping angka yang dibolongkan, bolongkan juga bentuk-bentuk seperti lingkaran atau persegi sebanyak sesuai angka. (Misal angka 2, bearti dibuat bentuk persegi sebanyak 2 buah).

- Kemudian buatlah bentuk-bentuk tersebut sesuai dengan ukuran yang dibolongkan menggunakan kain perca yang didalamnya diisi dengan busa atau beras atau kacang hijau. 
Cara Menggunakan:

- Ajaklah anak untuk bermain pengenalan angka.

- Perkenalkan angka kepada anak menggunakan potongan-potongan angka

- Setelah itu mintalah anak untuk mencocokan potongan angka tersebut pada bolonganbolongan pada kardus.

- Dan minta anak juga untuk menghitung jumlah bentuk yang terdapat pada kardus.

- Setelah itu tanyakan pada anak bentuk serta rasa raba yang anak rasakan.

\subsection{Bantu Mama Menjahit}

Tujuan:

Kegiatan ini membantu anak untuk melatih motorik halus mereka dengan kegiatan menjahit, serta melatih konsentrasi dan kesabaran anak.

Bahan dan Alat yang Diperlukan:

- Tali Sepatu

- Karton

- Gunting

- Pembolong kertas

Cara Membuat:

- Gambarlah sebuah bentuk topi pada karton

- Kemudian gunting topi tersebut mengikuti garis gambar

- Setelah itu bolongkanlah tepi-tepi pada topi tersebut

- Agar lebih menarik warnailah topi tersebut atau diberi hiasan

Cara Menggunakan:

- Berilah topi-topi tersebut kepada anak

- Mintalah anak untuk menjahit topi tersebut dengan mengunakan tali sepatu atau pita, dengan memasukan tali pada lubang-lubang yang telah tersedia

- Setelah itu minta anak untuk berkreasi dengan topi tersebut dengan memberi warna atau hiasan lainnya.

Catatan: Bentuk tidak dibatasi hanya dengan bentuk topi, tetapi dapat dikreasikan dengan bentuk lainnya seperti bentuk baju dan lain-lain.

\subsection{Yuk Berhitung...!}

Tujuan:

Mengajarkan anak untuk berhitung, melatih konsentrasi anak
Bahan dan Alat yang Diperlukan:

- Kartu domino

- Kecrekan (Sempoa)

Cara Bermain:

- Ajaklah anak untuk bermain domino berhitung (Jumlah pemain 2 atau lebih)

- Kemudian bagikan kartu kepada anak, tidak perlu terlalu banyak setiap anak mendapatkan 5 kartu.

- Kemudian tentukan siapakah pemain yang akan memulai permainan (dilakukan dengan Hompimpa)

- Jika sudah ditentukan, pemain yang pertama dapat mengambil 1 kartu pada teman yang berada disebelah kiri.

- Setelah mendapatkan kartu, keluarkan kartu tersebut kemudian pemain tersebut harus menghitung jumlah gambar yang terdapat pada kartu tersebut dengan menggunakan kecrekan.

- Jika pemain tersebut dapat menghitung dengan tepat, dia berhak untuk menyimpan kartu tersebut.

- Dan pemain yang mendapatkan kartu terbanyak maka dia pemenangnya.

\section{KESIMPULAN}

Dalam membentuk character building pada anak usia dini ada beberapa metode yang dapat digunakan, salah satu dari metode pada anak usia agar berpengaruh besar dan efektif dalam kehidupan nyata adalah dengan modeling (uswatun hasanah). Modeling adalah suatu metode pembelajaran dengan memberikan contoh perilaku dan suri tauladan yang baik kepada anak usia dini, baik langsung maupun tidak, sehingga pendidik dapat memperagakan cara pembuatan dengan memanfaatkan media pendidikan disekitar anak merupakan model bagi anak usia dini dalam mempraktekkan materi tertentu. Dalam menggunakan metode tersebut menjadi syarat mutlak bagi transformasi nilai pada anak usia dini, sebab anak cenderung meniru terhadap apa saja yang didengar, dilihat, dan dirasakan.

Dengan demikian dalam meningkatkan produktifitas dan kreatifitas pendidik yang optimal dan juga akan sangat berpengaruh besar terhadap perkembangan anak didik khususnya dalam penyampaian dan penyajian materi pembelajaran dalam proses belajar mengajar dengan menggunakan alat peraga. Alat peraga akan lebih 
menarik apabila disajikan dengan menarik, sehingga pendidik yang dapat mengoptimalkan kemampuan untuk membuat dan memanfaatkan alat peraga edukatif yang efektif dan efesien khususnya diberikan pada anak usia dini, selain daripada itu dengan memiliki kemampuan memadukan seluruh sumber daya dan dana yang potensial dengan terfokus anak usia dini dengan memanfaatkan lingkungan sekitar anak.

\section{DAFTAR ACUAN / PUSTAKA}

[1] De Porter, Bobbi, Mark Reardon dan Sarah Singer Nouri. Quantum Teaching; Mempraktikkan Quantum Learning di Ruang-ruang Kelas. Terjemahan dari Quantum Teaching; Orchestrating Stident Success. Oleh Ary Nilandari. Bandung; Kaifa. 2001.

[2] Fortson, R.L. \& Reiff, CJ. Early Chilhood Curriculum : Open Structures for integrated learning. Needham, MA; Allyn and Bacon. 1995.

[3] Haetley, R. Understanding Children's Play. New York NY. 1964. 